\title{
Leszek Kiełtyka*
}

\section{Wybrane systemy wspomagania zarządzania w przedsiębiorstwach o charakterze usługowym}

Streszczenie: w artykule scharakteryzowane zostały wybrane, podstawowe systemy wspomagania zarządzania w przedsiębiorstwach. Pod uwagę zostały wzięte przedsiębiorstwa głównie o profilu usługowym. Na sporą ilość systemów tego typu wykorzystywanych na naszym rynku przemysłowym, te scharakteryzowane dają ogólny wgląd na profil ich użyteczności. W trzech wybranych, powszechnie stosowanych systemach nowej generacji, wymienione zostały moduły szczególnej użyteczności, które odpowiadają analitycznym działom organizacji i są niezbędne do kompatybilnej współpracy pomiędzy przedsiębiorstwami podobnej branży.

Słowa kluczowe: systemy wspomagania zarządzania, wspomaganie decyzji, przedsiębiorstwo, informatyzacja.

\section{Wprowadzenie}

W ciągu ostatniego stulecia zmieniły się zapatrywania oraz podejścia praktyczne do zarządzania. Główny wpływ na to miały następujące czynniki:

- techniki przesyłania oraz przetwarzania informacji, którymi dysponowały organizacje,

- wskaźnik poziomu rozwoju organizacji wytwarzania,

- poziom rozwoju techniki produkcji,

- uwarunkowania społeczne, jak również kulturowe i polityczne otoczenia,

- poziom kwalifikacji oraz kultura osobista i etyka osób zarządzających.

Rola jaką pełnią zintegrowane systemy zarządzania w polskich przedsiębiorstwach jest ogromna, dowodzi tego fakt, że w 1997 roku

* Instytut Informacyjnych Systemów Zarządzania, Wydział Zarządzania, Politechnika Częstochowska. 
aż $92 \%$ ankietowanych przez Pentor dużych oraz średnich organizacji deklarowało korzystanie ze zintegrowanych systemów informatycznych, które wspierają zarządzanie (Programy wspomagajace zarządzanie, 1997, s. 109).

\section{Podstawowe systemy wspomagania zarządzania w podmiotach gospodarczych}

\section{Systemy informatyczne zarządzania}

Klasyfikacja Systemów Informatycznych Zarządzania (SIZ) nie od dziś jest obszarem analizy i dyskusji, stwarzającym problemem w trakcie rozważań aplikacyjnych występujących podczas obsługi w różnych resortach podmiotów gospodarczych. Tworzone systemy wykorzystują różne technologie i koncepcje projektantów, wspomagają występujące problemy organizacyjne oraz różne poziomy zarządzania.

Tabela 1 przedstawia klasyfikację SIZ pod względem rodzajów wspomagania, czyli poziomów zarządzania.

\section{Systemy wspomagania decyzji (SWD)}

Realizacja niezbędnych funkcji zarządzania jest związana z procesami podejmowania decyzji. Te procesy $w$ ramach różnych funkcji jako całość są budulcem komplementarnego systemu. Znaczenie poszczególnych składowych tegoż systemu dla całej organizacji jest zależne od funkcji zarządzania, którą pełnią oraz od ich miejsca w hierarchii wykorzystywania systemu (Klonowski, 2004, s. 26).

Podejmowanie decyzji niejednokrotnie sprowadza się do procesu o ograniczonej racjonalności, w którym dokonywane są wybory, na podstawie strukturalnych zasad, z jednoczesnym dostępem do ograniczonej informacji.

W latach osiemdziesiątych ubiegłego stulecia rozpoczęła się era szybkiego rozwoju systemów służących do wspomagania w podejmowaniu decyzji, głównie przez menedżerów (Kiełtyka, 2016, s. 4-11). Ewolucja w systemach wspomagania zarządzania spowodowała wykorzystanie dziedziny obejmującej rozwiązania na bazie sztucznej inteligencji. Działania te umożliwily automatyzację oceny poprawnego zarządzania na podstawie określonych zasad, a w konsekwencji doprowadzily do pojawienia się Inteligentnych Systemów Decyzyjnych oraz Systemów Eksperckich. Systemy te nazywane były Systemami Decyzyjnymi Kierownictwa. 
Tabela 1. Najczęściej wykorzystywane Systemy Informatyczne Zarządzania

\begin{tabular}{|l|l|c|}
\hline \multicolumn{1}{|c|}{ System } & \multicolumn{1}{|c|}{ Nazwa anglojęzyczna } & Skrót \\
\hline Systemy transakcyjne & Transaction Processing System & TPS \\
\hline Systemy nowoczesnego biura & Office Automation Systems & OAS \\
\hline Systemy informacyjne zarządzania & Management Information Systems & MIS \\
\hline $\begin{array}{l}\text { Systemy wspomagania zarządzania } \\
\text { produkcją }\end{array}$ & Manufacturing Resource Planning & MRP II \\
\hline Zintegrowane systemy zarządzania & $\begin{array}{l}\text { Computer Integrated Manufacturing } \\
\text { Enterprise Resource Plannig }\end{array}$ & $\begin{array}{l}\text { CIM } \\
\text { ERP }\end{array}$ \\
\hline Systemy wspomagania zarządzania & Management Support Systems & MSS \\
\hline Systemy wspomagania decyzji & Decision Support Systems & DSS \\
\hline Systemy informacyjne kierownictwa & Execitive Information Systems & EIS \\
\hline Systemy wspomagające kierownictwo & Executive Support Systems & ESS \\
\hline Systemy eksperckie & Expert Systems & ES \\
\hline
\end{tabular}

Źródło: opracowanie własne.

W odróżnieniu od systemów wspomagających przetwarzanie danych, SWD (Systemy Wspomagania Decyzji) są przeznaczone do:

- podnoszenia skuteczności, a nie tylko sprawności procesów decyzyjnych,

- wspierania, a nie negowania rozumowania decydenta,

- rozwiązywania problemów nieustrukturalizowanych bądź częściowo ustrukturalizowanych.

Najprostszy SWD powinien spełniać co najmniej cztery funkcje:

- wykorzystywać techniki oraz metody statystyczne i analityczne,

- wspomagać zarządzanie danymi,

- dynamizować analizę i strukturalizację wyników,

- umożliwiać wszechstronną prezentację wyników.

Znaczna część ważnych dla organizacji gospodarczej sytuacji związanych z podejmowaniem decyzji dotyczy problemów ekonomicznych, a te w dużej mierze cechuje niestabilność aspektów ilościowych oraz jakościowych, takich jak (Klonowski, op. cit., s. 31):

- ograniczoność środków mających wpływ na podejmowanie decyzji,

- wielość celów,

- niepewność i nieokreśloność danych,

- niedostatecznie określona koncepcja i metody rozwiązywania akceptowanych przez uczestników procesów, 
- brak akceptacji metod oceny wartości decyzji,

- brak stabilności w dziedzinie wartości oraz oceny skutków możliwych decyzji,

- niepewność i zmienność wiedzy na temat systemów wartości oraz indywidualnych preferencji osób decydujących.

Tabela 2. Wybrane istotne systemy wspomagające zarządzanie w przedsiębiorstwach

\begin{tabular}{|c|c|c|c|c|}
\hline Тyp decyzji & $\begin{array}{c}\text { Szczebel } \\
\text { operacyjny }\end{array}$ & $\begin{array}{c}\text { Szczebel } \\
\text { kierowniczy }\end{array}$ & $\begin{array}{l}\text { Planowanie } \\
\text { strategiczne }\end{array}$ & $\begin{array}{c}\text { Systemy } \\
\text { wspoma- } \\
\text { gające }\end{array}$ \\
\hline $\begin{array}{c}\text { Dobrze } \\
\text { ustrukturalizowane } \\
\text { Dobrze } \\
\text { definiowalne, } \\
\text { programowalne }\end{array}$ & $\begin{array}{l}\text { Księgowość } \\
\text { Zamówienia } \\
\text { materiałów } \\
\text { Rejestracja } \\
\text { dostaw } \\
\text { Przygotowanie } \\
\text { korespondencji }\end{array}$ & $\begin{array}{l}\text { Analiza budżetu } \\
\text { Krótkoterminowa } \\
\text { prognoza } \\
\text { Analizy } \\
\text { ekonomiczne } \\
\text { Sprawozdania } \\
\text { podatkowe } \\
\end{array}$ & $\begin{array}{l}\text { Lokalizacja } \\
\text { inwestycji } \\
\text { System } \\
\text { dystrybucji } \\
\text { Szkolenie } \\
\text { personelu }\end{array}$ & $\begin{array}{l}\text { TPS } \\
\text { OAS } \\
\text { MIS } \\
\text { ES } \\
\text { MRP } \\
\text { CAQ }\end{array}$ \\
\hline $\begin{array}{c}\text { Słabo } \\
\text { ustrukturalizowane }\end{array}$ & $\begin{array}{l}\text { Techniczne } \\
\text { przygotowanie } \\
\text { produkcji } \\
\text { Gospodarka } \\
\text { magazynowa }\end{array}$ & $\begin{array}{l}\text { Kontrola jakości } \\
\text { Opracowanie } \\
\text { budżetu } \\
\text { Analiza kosztów } \\
\text { Harmonogramowa- } \\
\text { nie projektów } \\
\text { Opracowanie sys- } \\
\text { temu wynagrodzeń }\end{array}$ & $\begin{array}{c}\text { Ocena } \\
\text { kredytu } \\
\text { Planowanie } \\
\text { nowego pro- } \\
\text { duktu } \\
\text { Określenie } \\
\text { centrum kosz- } \\
\text { tów i zysku } \\
\text { Ocena projek- } \\
\text { tów inwesty- } \\
\text { cyjnych } \\
\end{array}$ & $\begin{array}{c}\text { MIS } \\
\text { DSS } \\
\text { ES } \\
\text { CRM } \\
\text { MRP II } \\
\text { ERP } \\
\text { CIM } \\
\text { CAQ } \\
\text { CAP } \\
\text { CAE } \\
\text { CAM } \\
\end{array}$ \\
\hline $\begin{array}{c}\text { Nieustrukturalizo- } \\
\text { wane } \\
\text { Trudno } \\
\text { definiowalne } \\
\text { Nieprogramowalne } \\
\text { Rozmyte } \\
\text { Heurystyki } \\
\text { Wielokryterialne } \\
\text { Długi horyzont } \\
\text { czasowy }\end{array}$ & $\begin{array}{l}\text { Wybór dostawcy } \\
\text { surowców } \\
\text { Zakup } \\
\text { oprogramowania }\end{array}$ & $\begin{array}{c}\text { Negocjacje } \\
\text { Rekrutowanie kadry } \\
\text { kierowniczej } \\
\text { Zakup komputerów } \\
\text { Marketing }\end{array}$ & $\begin{array}{c}\text { Planowanie } \\
\text { R\&D } \\
\text { Rozwój } \\
\text { nowej } \\
\text { technologii } \\
\text { Polityka so- } \\
\text { cjalna firmy } \\
\text { Polityka } \\
\text { współpracy } \\
\text { z dostawcami } \\
\text { i odbiorcami }\end{array}$ & $\begin{array}{c}\text { DSS } \\
\text { ES } \\
\text { ESS-EIS }\end{array}$ \\
\hline
\end{tabular}

Źródło: opracowanie własne.

W momencie przekazania decyzji komórkom wykonawczym, po wcześniejszej konsultacji z ich wykonawcami, zaczyna się faza realizacji, która jest nieodłączną częścią procesu decyzyjnego. Podczas poleceń przekazywane są informacje dotyczące faktycznego stanu realizowanych 
zadań. Natomiast, gdy pojawiają się odchylenia od przyjętego toku realizacji zadań, generowane są decyzje regulujące. Odchylenia o małym znaczeniu korygowane są od razu, z pominięciem procesu podejmowania kolejnych decyzji regulujących.

Proces decyzyjny ma specyfikację procesu ramowego, który w praktyce jest zwykle upraszczany i modyfikowany, zależny od wagi i przedmiotu podejmowanej decyzji oraz sytuacji. Najczęściej decydenci zlecają opracowywanie decyzji strategicznych komórkom sztabowym, natomiast decyzje operatywne są przygotowywane przez nich osobiście, lub też delegują uprawnienia do ich podejmowania niższym szczeblom zarządzania (Peszko, 2002, s. 89).

Często podczas podejmowania decyzji organy decyzyjne muszą korzystać z najnowszych dostępnych technologii informacyjnych. Nie zawsze drogą logicznego rozumowania oraz „wspaniałych” rozwiązań da się wykryć nieoczekiwane problemy. Budując odpowiedni model i wprowadzając go do komputera, jako system wspomagający, większość problemów jest do rozwiązania, a otrzymywane wyniki są w większości przypadków obiecujące.

\section{Systemy Informowania Kierownictwa (SIK)}

Stanowisko kierownicze odróżnia się od wykonawczego tym, że daje kierownikowi możliwość decydowania nie tylko o swoim działaniu, ale również o działaniu podwładnych. Wiąże się to z obowiązkiem rozwiązywania problemów decyzyjnych, dotyczących zakresu działania danej jednostki organizacyjnej oraz odpowiedzialnością za decyzje podejmowane na stanowisku kierowniczym.

Przejście od zarządzania informacją do zarządzania wiedzą podkreśla fakt, iż zarządzanie to polega na porządkowaniu wiedzy i informacji zawartych w dokumentach (Kiełtyka (red.), 2006, s. 65).

System informowania kierownictwa jest źródłem informacji, dla odpowiednich szczebli zarządzania, niezbędnych do skutecznego wykonywania określonych zadań decyzyjnych. Potrzeby informacyjne kadry kierowniczej są różne w zależności od szczebla w piramidzie hierarchii. Kierownicy naczelni wymagają danych dotyczących planowania oraz kontroli strategicznej, pozyskiwanej przede wszystkim ze źródeł zewnętrznych. Kierownicy średniego szczebla potrzebują informacji zarówno ze źródeł zewnętrznych, jak i wewnętrznych.

Dobre zaprojektowanie oraz skuteczne wdrożenie SIK wymaga (Kiełtyka, 2002, s. 396-407):

- szczegółowego rozważenia kosztów systemu,

- włączenia użytkowników w grono zespołu projektującego, 
- starannego przeszkolenia operatorów oraz użytkowników systemu,

- wyselekcjonowania najważniejszych informacji,

- wypróbowania systemu zanim zostanie wdrożony.

\section{Najistotniejsze etapy projektowania systemu informacyjnego dla przedsiębiorstwa}

- Definiowanie problemu, na które składają się następujące czynności:

- analiza przedprojektowa (musi „dojrzeć” świadomość, że faktycznie potrzebny jest nowy system lub modyfikacja istniejącego),

- określenie zadań (po analizie otoczenia i potrzeb użytkownika sprecyzować cele),

- powołanie zespołu, odpowiedzialnego za opracowanie strategii projektowej (powinien to być zespół wieloosobowy skupiający ludzi o różnych specjalnościach; kierownikiem zespołu powinien być ktoś o zdolnościach menedżerskich).

- Analiza sytuacji, której wynikiem jest:

- sprecyzowanie ograniczeń w budowie i funkcjonowaniu systemu (należy przyjąć pole rozwiązań - liczba możliwych strategii projektowych),

- wyznaczenie metody oceny skuteczności realizowanego projektu (określić w jaki sposób przy zdefiniowanych ograniczeniach można osiągnąć cel),

- określenie kryteriów oceny składowych strategii (ocenić ryzyko przyjęcia określonej strategii, oszacować ryzyko biorąc pod uwagę zmieniające się warunki w organizacji),

- określenie zbioru składowych strategii projektowych (zbiór strategii musi być najpełniejszy).

- Rozwiązanie - sformułowanie strategii projektowej:

- charakterystyka składowych strategii i opracowanie odpowiedniego harmonogramu ich realizacji (ocenić w jakim stopniu przyjęcie strategii pozwoli na realizację celów),

- przeprowadzenie obliczeń i uporządkowanie zbioru poszczególnych strategii (na podstawie otrzymanych charakterystyk dokonujemy obliczeń - efekt to uporządkowana lista strategii),

- przedstawienie do zatwierdzenia zebranych możliwych strategii projektowych,

- wstępny wybór strategii projektowej.

- Weryfikacja zasobów.

- Realizacja (organizacja procesu; powołanie zespołu projektowego). 


\section{Systemy eksperckie (SE)}

Systemy eksperckie są formą sztucznej inteligencji. Systemy te, to jednoznaczne aplikacje zorientowane na użytkownika. W procesie budowy Systemu Eksperckiego należy założyć, że wiedza w nim zawarta będzie tylko częścią wiedzy eksperta, od którego ją uzyskano, a odpowiedzi przekazywane przez system mogą być niejednokrotnie mniej precyzyjne niż odpowiedzi eksperta.

System ekspercki jest programem komputerowym, który stosuje modele wiedzy i procedury wnioskowania w celu rozwiązywania problemów. Wiedza taka składa się z faktów i reguł wnioskowania. System ekspercki jest zwykle budowany w dialogu $\mathrm{z}$ ekspertem $w$ danej dziedzinie nazywanym obecnie, coraz częściej, inżynierem wiedzy. Pozyskiwanie i modelowanie wiedzy oraz tworzenie systemu komputerowego dla rozwiązywania problemów nazywane jest inżynierią wiedzy (Sokołowski, Wrzalik, Pudło, 2015, s. 89-97).

Systemy eksperckie są głównym elementem systemów wspomagania decyzji ekonomicznych. Oferują one często wysoki poziom ekspertyzy, która jest przeprowadzana według jednolitych, dobrze określonych norm. Osiąga się w ten sposób zwiększenie dostępności profesjonalnych ekspertyz, jednocześnie redukując koszty przy zachowaniu niezmiennego w czasie oraz niezależnego od warunków toku dedukowania.

Istotne obszary i zagadnienia obejmujące strukturę SE:

- zadanie wymaga bardziej rozumowania symbolicznego niż obliczeń numerycznych,

- używane jest przeszukiwanie heurystyczne a nie procedury algorytmiczne,

- wiedza specyficzna dla danej dziedziny dominuje nad ogólną,

- problem musi mieć dobrze zdefiniowane rozwiązania, których założenia muszą być ustalone na początku,

- logika wnioskowania jest z góry określona,

- zadanie musi być o możliwych do ogarnięcia rozmiarach lecz złożone na tyle, by opłacało się stosować SE,

- ekspert musi być chętny do współpracy.

Oprogramowanie Systemów Eksperckich pozwala na rozwiązywanie problemów w sposób podobny do ludzkiego rozumowania oraz uzasadnia przyjęte rozwiązania dzięki generowaniu:

- listy reguł wnioskowania, czyli tzw. heurystyk,

- logicznego uzasadnienia drogi postępowania,

- listy rozwiązań alternatywnych z wyjaśnieniem ich odrzucenia.

Jednym z kierunków ewolucji Systemów Informatycznych Zarządzania jest łączenie różnych dokonań z obszaru informacyjnych systemów 
wspomagania zarządzania. Działania skierowane są na integrację systemów eksperckich, systemów indukcyjnych, sztucznych sieci neuronowych, jak również na dokonania, które mają swoje fundamenty w algorytmach genetycznych, zbiorach przybliżonych oraz logice rozmytej. Inteligentne systemy informatyczne są często określane jako systemy hybrydowe. Celem wykorzystania tychże systemów jest uzyskanie odpowiedniego potencjału sztucznej inteligencji, który jest dostępny dla każdej rozpatrywanej analizy przydatności danej metody. Hybrydowe systemy eksperckie zawierają algorytmy klasycznej matematyki w połączeniu $\mathrm{z}$ heurystykami cechującymi sztuczną inteligencję i umożliwiają podejmowanie decyzji tak ilościowych, jak i jakościowych.

\section{Ewolucja systemów zarządzania zasobami przedsiębiorstwa}

Dynamiczna ewolucja rozwiązań informatycznych objęła również systemy klasy ERP. Nie przeszkodził temu brak formalnej specyfikacji architektury tych systemów. Autonomiczność struktur-modułów, wchodzących $w$ ich skład, uwypuklana jest $\mathrm{w}$ celu podkreślenia znaczenia technologii ewoluujących rozwiązań internetowych mających centralne znaczenie.

W praktyce oznacza to otwarcie się systemu na otoczenie, co nie dotyczy funkcji eksportu i importu danych, ale zwraca uwagę na wymianę danych on-line, czego narzędziem rozumianym przez większość systemów jest język XML. Uwidaczniają się zmiany dotyczące filozofii funkcjonowania systemu, jednak nie jako efekt tworzenia nowych modułów. Ze zmianą technologii rośnie funkcjonalność rozwiązania i możliwości komponowania rozwiązań złożonych z funkcjonalności modułów systemów różnych producentów.

W miarę rozwoju nowych technologii, wzrastały również wymagania przedsiębiorców co do rozwoju SWZ. Wraz z dynamicznym rozwojem techniki informatycznej rozpoczęła się ewolucja i implementacja pakietów Informatycznych Systemów Zarządzania (ISZ). Podstawowe standardy $\mathrm{w}$ ujęciu chronologicznym przedstawiają się następująco (Kiełtyka, 2002, s. 408):

- MRP I - planowanie pojawiających się potrzeb materiałowych,

- CL-MRP - funkcje MRP I oraz zdolności produkcyjnej w zamkniętym otoczeniu,

- MRP II - planowanie zasobów produkcyjnych,

- ERP - planowanie zasobów przedsiębiorstwa, 
- DEM - dynamiczne modelowanie przedsiębiorstwa,

- ERP II - planowanie zasobów przedsiębiorstwa na podbudowie jego komponentów.

$\mathrm{Na}$ bazie standardu MRP II powstały nowe wyspecjalizowane metody, takie jak:

- JiT - planowanie zasobów dokładnie na czas,

- OPT - technologia optymalizacji produkcji,

- DRP - planowanie zasobów dystrybucyjnych.

Zintegrowane systemy informatyczne, które wspomagają zarządzanie, są niewątpliwie rozwiązaniem o dużym stopniu funkcjonalności oraz integracji. Systemy te przechodziły kolejne etapy (Adamczewski, 2004, s. 165):

- Systemy Transakcyjne Przetwarzania Danych,

- Systemy Informacyjne Zarządzania - SBD - określane często jako MIS. Na swoim poziomie rozwoju funkcjonalnego są utożsamiane z systemami Zarządzania Bazami Danych,

- Systemy Wspomagania Decyzji,

- Systemy Eksperckie,

- Systemy Informowania Kierownictwa - EIS, często utożsamiane są z Systemami Wspomagania Kierownictwa,

- Systemy Sztucznej Inteligencji - SSI, utożsamia się je bardzo często jako Systemy Sieci Neuronowych oraz określa jako ANN,

- Zintegrowane systemy informatyczne ZSI.

Ewolucja systemów komputerowego wspomagania zarządzania organizacjami, a w szczególności przedsiębiorstwami został przedstawiona i opisana w literaturze (Kiełtyka, 2002, s. 396-424). Wszystkie zaprezentowane i scharakteryzowane tam moduły są aktualnie udoskonalane na bazie postępu i rozwoju technologicznego systemów informatycznych.

\section{Przykładowe aktualne systemy zarządzania w przedsiębiorstwach usługowych}

Współczesne organizacje działają w zmieniających się warunkach zewnętrznych. Niewielkie zmiany w otoczeniu przedsiębiorstwa są bodźcem do doskonalenia, lub też zmiany, odpowiednio do ich stopnia i poziomu strategii. Ważne jest posiadanie aktualnych map procesów gospodarczych przedsiębiorstwa tak, aby móc jak najlepiej dostosować się do pojawiających się nieuniknionych zmian. Jednocześnie, powiązania między składnikami organizacji stają się coraz bardziej kompleksowe. Naturalnym tego wynikiem jest przechodzenie od podejścia funkcjonalnego 
w organizacjach do podejścia procesowego. Przedsiębiorstwa, które chcą osiągnąc sukces na rynku powinny dbać o efektywny przebieg swoich procesów biznesowych. Aby być konkurencyjnym na rynku przedsiębiorstwo musi jak najlepiej zaspokajać potrzeby klienta i w sposób ciągły je monitorować. Bardzo ważne jest również obniżanie kosztów oraz skracanie cykli przebiegów procesów. Zgodnie z tym istotną rolę odgrywa właściwie zaprojektowany system zarządzania przedsiębiorstwem, co wymaga stosowania odpowiednich rozwiązań informatycznych (Wilimowska, Zalewska, 2004, s. 78).

\section{Korzyści wynikające $z$ informatyzacji zarządzania}

Najnowsze tendencje w obszarze systemów zintegrowanych są architekturami zorientowanymi na współdziałanie oraz na obsługę i koordynacje usług. Umożliwia to bardziej szczegółowe koordynowanie oraz współdziałanie platformy B2B wielu partnerskich systemów zintegrowanych (ZSI), jak również ich użytkowników ukierunkowanych na standard wymiany informacji XML.

Zintegrowane systemy obsługują wszystkie płaszczyzny funkcjonowania przedsiębiorstwa oraz optymalizują procesy tak wewnętrzne, jak $\mathrm{i}$ te zachodzące $\mathrm{w}$ najbliższym otoczeniu organizacji, oferując gotowe narzędzia i pozwalając na automatyzację wymiany danych z kooperantami należącymi do tego samego łańcucha logistycznego. Ponadto mają możliwości dynamicznej konfiguracji, co pozwala na dopasowanie ich funkcjonalności do sposobu funkcjonowania konkretnego przedsiębiorstwa czy kooperującej z nim organizacji.

Aplikacje informatyczne, które wspomagają działalność przedsiębiorstwa, działają już na płaszczyźnie szczebla operacyjnego. Kodują dane każdego klienta tworząc dotychczasowy bilans $\mathrm{z}$ danym kontrahentem. Ułatwia to przyszłe działania związane z tym kontrahentem. Na potrzeby monitorowania relacji z kontrahentami stworzono systemy CRM, które podwyższają poziom kultury przedsiębiorstwa. Kultura rozumiana jest tu jako suma wartości wnoszonych przez ludzi oraz wiedza zgromadzona $w$ trakcie funkcjonowania organizacji i narzędzia jakimi ona się posługuje. Awansowanie na kolejny, wyższy poziom wiąże się niestety z zagrożeniami. Pojawiają się nowe sytuacje oraz nowe perspektywy. Osiągnięcie tego poziomu jest często nieodzownym warunkiem przetrwania na nieustannie zmieniającym się rynku konkurencyjnym. Różnorodna gama narzędzi jakimi dysponuje organizacja to maszyny, urządzenia, oprogramowanie wspierające działalność przedsiębiorstwa. Biorąc pod uwagę oprogramowanie nie sposób pominąć najważniejszych aplikacji wspierających produkcję, logistykę, finanse organizacji oraz tych, które nie dotyczą bezpośrednio relacji z klientem, aplikacji typu back office. Systemy 
front office mają natomiast za zadanie nadzorowanie kontaktów z klientem (CRM). Pozwala to na monitorowanie spływu każdego towaru z przedsiębiorstwa, a jednocześnie stosowanie elastycznych kryteriów cen w następnej transakcji. Jako przykład wymienić można takie aplikacje jak: Enova (https://www.google.pl/?gws_rd=ssl\#q=system+enova, [dostęp: 18.11.2016]), Symfonia (https://www.google.pl/?gws_rd=ssl\#q= SYMFONIA, [dostęp: 18.11.2016]), RAKS (https://www.google.pl/?gws _rd=ssl\#q=RAKS, [dostęp: 18.11.2016]).

Aplikacje te dostarczają mechanizmów pozwalających na ocenę procesu sprzedaży przez właścicieli, możliwości ingerowania w system cen, jak również zarządzanie grupami pracowników, którzy obsługują proces sprzedaży.

Głównym miernikiem w zarządzaniu sprzedażą, w obszarze taktycznym, jest wyznacznik finansowy uwzględniający wymogi skierowane na systemy finansowo-księgowe. Źródłem priorytetowym informacji stają się same systemy. O tym właśnie decyduje główna cecha jaką jest wiarygodność - co oznacza, że wszystkie dane są sprawdzone, natomiast skutki finansowe dla przedsiębiorstwa są określone i istnieje możliwość wyłonienia prawidłowości w rzeczywistych procesach. Przeprowadzona transakcja ma odzwierciedlenie w postaci zapisu na kontach, co umożliwia analizowanie skutków podejmowanych decyzji w określonym czasie oraz racjonalne reakcje na przyszłe wyniki.

Szczebel zarządzania strategicznego wymaga odpowiedzi na pytania dotyczące działalności organizacji w dłuższej perspektywie czasowej. Wynikiem tego jest brak możliwości precyzyjnej odpowiedzi na zapytanie o rodzaj produktu, jego cenę, zainteresowaną grupę klientów. Pozwala jednak wskazać jakimi cechami powinna charakteryzować się grupa produktów oraz grupa odbiorców, tak by osiągnąć cel strategiczny, a więc zwiększyć wartość przedsiębiorstwa. Szybko zmieniające się otoczenie, zmusza coraz większą liczbę organizacji do zmiany swojej struktury, aby móc nadążać za wyzwaniami oraz oczekiwaniami środowiska. Staje się to dla nich swego rodzaju sposobem na życie. Ich głównym celem jest więc bycie konkurencyjnymi i efektywnymi. Ważnym jest, aby z każdą zmianą oraz innowacją organizacja umiejętnie radziła sobie z ryzykiem. Na pomoc, w tej sytuacji, przychodzą aplikacje informatyczne przeznaczone do wspomagania zarządzania.

Stosowane systemy klasy ZSI pozwalają odpowiadać na wyzwania nowej gospodarki dotyczące kontroli kosztów, elastyczności w odpowiedzi na oczekiwania konsumentów oraz aktualnej oceny tego, co się dzieje w przedsiębiorstwie z jego zasobami, w sposób umożliwiający podejmowanie trafnych decyzji. 
Ponieważ system zarządzania przedsiębiorstwem powinien przyczyniać się do zasadniczych korzyści odczuwalnych przez klientów, zazwyczaj rozpoczyna się od integracji działów sprzedaży, produkcji oraz zakupów. Wówczas możliwy staje się scenariusz, w którym dział sprzedaży przyjmując zamówienie od klientów oraz wprowadzając je do systemu daje możliwość wygenerowania zleceń produkcyjnych. Pion produkcji układa główny plan realizacji, w ramach którego rezerwuje się dostępne zasoby przedsiębiorstwa i dobiera: liczbę godzin pracy pracowników, jak również maszyn, ilość półfabrykatów, surowców oraz odpadów użytkowych, a także planuje się zakupy na potrzebnych komponentów. Jeśli obieg informacji działa poprawnie, skraca to cykl wytwórczy oraz udostępnia śledzenie zaawansowania produkcji. Zrealizowanie wszystkich zadań produkcyjnych umożliwia przetransportowanie produktu do magazynu, co zmienia stan zapasów, jednocześnie informując dział sprzedaży o zrealizowaniu zamówienia.

Podstawowymi wyznacznikami efektywności są: rzeczywisty czas dostępu do danych, do informacji oraz przyjazny dla użytkownika zintegrowany system informatyczny.

\section{Cechy funkcjonalności systemów zarządzania w przedsiębiorstwach usługowych}

System Enova (https://www.google.pl/?gws_rd=ssl\#q=system+ enova, [dostęp: 18.11.2016]) jest narzędziem należącym do nowej generacji programów wykorzystywanych w obszarze zarządzania usługami. Funkcjonalnie system obejmuje następujące główne moduły:

- Ewidencja Środków Pieniężnych.

- Księga Inwentarzowa.

- Kadry, Płace, Księgowość.

- Faktury.

W systemie zintegrowanym informacje, dokumenty przechowywane są w konkretnym jednym miejscu, mimo to dostępne są z wielu poziomów w programie, co ułatwia oraz przyśpiesza realizację procesów zachodzących w danym przedsiębiorstwie. Do programu Enova dostęp mogą mieć pracownicy o konfigurowalnych uprawnieniach. W systemie dane przepływają kontekstowo między poszczególnymi modułami, które odpowiadają analitycznym działom organizacji, stanowiskom pracy oraz funkcjom pełnionym w przedsiębiorstwie.

Program ma budowę modułową, co oznacza, że każdy moduł ma swoje zadania wspomagania określonego obszaru w działalności organizacji. Moduły te dotyczą między innymi:

- zarządzania kadrami,

- środków finansowych, 
- ewidencjonowania środków pieniężnych,

- fakturowania,

- gospodarki magazynowej,

- działu sprzedaży,

- księgi inwentarzowej,

- środków trwałych,

- księgowości,

- relacji z klientami,

- windykacji,

- sprzedaży mobilnej.

Dla przykładu system, który funkcjonuje w drukarni musi posiadać możliwość przygotowywania kosztorysów biorąc pod uwagę zapasy magazynowe oraz koszty towaru i dostępne gramatury papieru. Uwzględnione powinny być koszty farb i oszacowane ich zużycie, nie można pominąć obliczenia czasu pracy maszyn potrzebnego, aby zrealizować konkretne zlecenia oraz uwzględniać podczas kalkulacji zleceń amortyzację, jak również koszty leasingu.

Zintegrowany system Enova opracowany został do współpracy z różnym oprogramowaniem branżowym i specjalistycznym, co umożliwia koncentrację całości funkcjonowania firmy w jednej aplikacji. Nie ma potrzeby żonglowania wieloma oddzielnymi programami, a co za tym idzie marnowania, w ten sposób, cennego czasu i środków.

Oprogramowanie Enova wspomaga działanie przedsiębiorstw od 2008 roku. Moduł CRM przyczynia się do skutecznego budowania trwałych relacji z klientami. Program pozwala na zautomatyzowanie przebiegu procesów logistycznych oraz biznesowych w firmie. Umożliwia również generowanie ofert oraz dokumentacji elektronicznej, np. w postaci plików pdf. Dzięki swojej elastyczności rozwiązanie to idealnie odpowiada na rosnące potrzeby firmy.

RAKSSQL to pakiet, który powstał na bazie prawie dwudziestoletnich doświadczeń firmy RAKS (https://www.google.pl/?gws_rd=ssl\#q=RAKS [dostęp: 18.11.2016]), która specjalizuje się w tworzeniu oprogramowania wspierającego płaszczyzny zarządzania przedsiębiorstwem. Jest to polski produkt, dostosowany do krajowych nowoczesnych realiów gospodarczych, jak również standardów Unii Europejskiej.

System RAKSSQL skierowany jest do organizacji produkcyjnych, handlowych i usługowych. Jest zbudowany z kilkunastu modułów, które funkcjonują samodzielnie lub w całości jako jeden zintegrowany system. Zapewnia to możliwość zarówno pracy jednostanowiskowej, jak też pracy w sieci oraz dostosowuje się do wymogów klienta pracy zdalnej przez sieć internetową. 
System Symfonia (https://www.google.pl/?gws_rd=ssl\#q=SYMFONIA, [dostęp: 18.11.2016]) to kompleksowy produkt wspomagający zarządzanie obszarem finansowo-księgowym, kadrowo-płacowym oraz sprzedażowym w przedsiębiorstwach o dowolnym profilu działalności, w których rozliczenia bazują na pełnej księgowości. Programy Sage Symfonia umożliwiają obsługę wielu przedsiębiorstw i równoczesną pracę wielu użytkowników w sieci. Stosowana jest wymiana informacji pomiędzy programami poprzez mechanizm integracji baz danych oraz eksport $\mathrm{i}$ import z wykorzystaniem plików tekstowych. Opcje dodatkowe e-Box oraz raporty graficzne stanowią rozszerzenie funkcjonalności produktu. Sage Symfonia współpracuje z serwisem internetowym przez co umożliwia szybką i prostą wymianę dokumentów elektronicznych. Ułatwia bezpieczny obrót fakturami elektronicznymi z wieloma kontrahentami jednocześnie, zgodnie $\mathrm{z}$ aktualnymi przepisami prawa, bez konieczności posiadania podpisu kwalifikowanego.

Zadaniem programów Symfonia jest wspomaganie działania przedsiębiorstw poprzez ułatwienie rejestracji zdarzeń gospodarczych i wystawianie odpowiednich dokumentów. System jest stale i na bieżąco aktualizowany. Opis wszystkich nowości i zmian w programie można znaleźć w Internecie.

Procedura wyboru ZSI jest bardzo ważnym elementem, który należy połączyć z projektem wdrożeniowym. Nie może być uważana jako coś oczywistego, gdyż sama w sobie powinna stanowić wyszczególniony etap z przydzielonym czasem i realizacją koniecznych zasobów proceduralnych.

Przydatność pakietów ocenia się ze względu na ich funkcjonalności, na bieżąco deklarowanej przez dostawców, ogólnodostępnych modeli referencyjnych funkcji oferowanych w pakietach oraz oceny wizyt referencyjnych u użytkowników.

W selekcji wstępnej zostaje wybrane kilkanaście pakietów przeznaczonych następnie do dalszej analizy.

Końcowa selekcja dotyczy tej grupy systemów, która była wstępnie wyznaczona podczas procedur analitycznych i porównawczych z dokładnością do funkcji elementarnych i uwzględnia ogólne kryteria wyboru. W wyniku tego etapu selekcji powinno się wyróżnić dwa lub trzy pakiety. Selekcja wstępna, jak również końcowa, w zdecydowany sposób obciąża ekspertów i analityków oraz przedstawicieli zespołu koordynacyjnego. 


\section{Podsumowanie}

Zasady wdrażania zintegrowanych systemów informatycznych zarządzania zależą przede wszystkim od zakresu dziedzinowego wybranych i obsługiwanych funkcji, zakresu wymaganej adaptacji, właściwości technicznych pakietów, strategii opracowanych przez firmy softwareowe i warunków istotnych dla użytkownika. Bez względu na rozmiar wielości stosowanych podejść, sformułować można kilka ogólnych zasad implementacji systemów podobnego typu. Wnioski wydedukowane z analizy oraz strategia procedur informatyzacji budowane są na bazie ogólnej strategii danej organizacji i powinny one określać cele, zakres wszystkich zmian, oczekiwane usprawnienia, kolejność i hierarchię (Nowaczyk, 2000, s. 57). Powinny również zostać sformułowane odpowiednie wymagania na wszystkich poziomach podstawowych obszarów dziedzinowych oraz istotnych funkcji i procesów. Kryteria selekcji oraz wybór pakietu są ustanawiane przez warunki i wymagania, mają tu też znaczenie warunki kontraktu, który zostanie zawarty przez użytkownika $\mathrm{z}$ dystrybutorem licencji na użytkowanie systemu wspomagania zarządzania.

Planowanie oraz sterowanie zasobami materiałowymi przedsiębiorstwa jest, swego rodzaju, łącznikiem poszczególnych zadań w jeden kompleksowy system zawarty w łańcuchu dostaw. Dotyczy to takich zakresów jak: przewidywanie oraz określanie wielkości zamówień, określanie momentów rozpoczęcia kompletacji i wielkości zapasów w magazynach oraz w procesie wytwarzania, terminów dostaw materiałów. Celem integracji jest osiągnięcie dużej efektywności łańcucha dostaw zachowując jednocześnie zdolności do rozwoju elastycznego reagowania na potrzeby klienta oraz wewnętrzne przedsiębiorstwa.

Zamierzone cele są realizowane poprzez weryfikowanie łańcucha dostaw dzięki integracji działalności poszczególnych podmiotów, które są związane z przedsiębiorstwem. Fundamentem skutecznej współpracy jest ścisła i efektywna komunikacja (Sitko, 2007, s. 2).

Sprawnie działający, zintegrowany system informatyczny wspomagania zarządzania potrafi obsługiwać coraz większą ilość danych poprzez proces przetwarzania. System ten selekcjonuje, filtruje oraz systematyzuje dane tak, aby użytkownik mógł swobodnie w każdej chwili do nich dotrzeć i z nich korzystać. Takie zastosowanie systemu powoduje, że organizacja pracy jest bardziej skuteczna. Niezbędna jest jednak, wymagana od pracowników kompleksowa wiedza. Dlatego też system informatyczny powinien pełnić rolę „eksperta” w łańcuchu dostaw i zamówień. Wymagania takie stawia również presja konkurencji, gdyż analizy, koncentrujące się tylko na jednym aspekcie działania i funkcjonowania 
przedsiębiorstwa, nie są wystarczające. Ergonomiczność wyboru przez przedsiębiorstwo systemu wspomagania zarządzania jest miarą jego konkurencyjności na rynku.

\title{
BIBLIOGRAFIA
}

Adamczewski P. (2004), Zintegrowane systemy informatyczne $w$ praktyce, Mikom, Warszawa.

Kiełtyka L. (2002), Komunikacja w zarządzaniu. Techniki, narzędzia i formy przekazu informacji, Agencja Wydawnicza Placet, Warszawa.

Kiełtyka L. (red.) (2006), Aplikacje technik multimedialnych w organizacjach gospodarczych, KTEE, Kielce.

Kiełtyka L. (2016), Rola menedżera we współczesnych organizacjach, „Przegląd Organizacji”, $\mathrm{nr} 8$.

Klonowski Z.J. (2004), Systemy informatyczne zarządzania przedsiębiorstwem, OWPW, Wrocław.

Nowaczyk A. (2000), Praktyczne aspekty wyboru i wdrożenia systemu klasy ERP, [w:] Knosala R. (red.), Komputerowo zintegrowane zarządzanie, zbiór referatów III konferencji, Zakopane 10-12 stycznia 2000, t. II, WNT, Warszawa.

Peszko A. (2002), Elementy organizacji i zarządzania przedsiębiorstwem, UWND, Kraków.

Programy wspomagajace zarządzanie (1997), Wydawnictwo Businessman Magazine, sierpień.

Sitko J. (2007), Wplyw elementów systemu informatycznego na rozwój gospodarki materiatowej, SCENO, Kielce.

Sokołowski A., Wrzalik A., Pudło M. (2015), Koncepcja zintegrowanej platformy oceny kompetencji z wykorzystaniem systemu ekspertowego, [w:] Kiełtyka L., Jędrzejczyk W. (red.), Wykorzystanie potencjału wspótczesnych technologii informacyjnych w zarzadzaniu organizacjami, Wydawnictwo Politechniki Częstochowskiej, Częstochowa.

Wilimowska Z., Zalewska M. (2004), Model procesu biznesowego przedsiębiorstwa produkcyjnego, „Zarządzanie Przedsiębiorstwem”, vol. 7, $\mathrm{nr} 2$.

https://www.google.pl/?gws_rd=ssl\#q=system+enova, [dostęp: 18.11.2016].

https://www.google.pl/?gws_rd=ssl\#q=RAKS, [dostęp: 18.11.2016].

https://www.google.pl/?gws_rd=ssl\#q=SYMFONIA, [dostęp: 18.11.2016].

\section{CHOSEN MANAGEMENT SUPPORT SYSTEMS IN SERVICE PROVIDING ENTERPRISES}

\begin{abstract}
Basic management support systems in enterprises have been characterized in the present paper. The analyzed enterprises are mainly the service providing ones. Out of a large number of systems of this kind, the characterized ones provide a general insight into their utility profile. In selected three, commonly applied new
\end{abstract}


generation systems, particular utility modules have been distinguished, which represent the analytic departments of organizations and are indispensable for compatible co-operation among a similar industry enterprises.

Keywords: management support systems, decision support, enterprise informatization. 